\title{
Expression of the Chicken c-src Gene in COS Cells
}

\author{
TONA M. GILMER $†$ \\ Department of Microbiology and Immunology, University of North Carolina at Chapel Hill, Chapel Hill, \\ North Carolina 27514
}

Received 2 November 1983/Accepted 15 February 1984

\begin{abstract}
The cellular homolog of the Rous sarcoma virus transforming gene ( $\mathrm{v}-\mathrm{src})$ was cloned into a plasmid containing the simian virus $\mathbf{4 0}$ origin of replication and transcriptional signals. This recombinant plasmid, designated pSVOHCS11, directs the synthesis of relatively high levels of c-src mRNA and c-src protein $\left(\mathrm{pp60} 0^{\mathrm{c}-s r c}\right)$, when the plasmid is studied 48 to $72 \mathrm{~h}$ after calcium phosphate-mediated DNA transfection of COS (monkey) cells. The level of c-src mRNA synthesis is 50-fold higher than the amount of c-src RNA produced in uninfected chicken embryo fibroblasts. Furthermore, the level of pp60-src expressed in pSVOHCS11-transfected COS cells is approximately the same as that of pp60 ${ }^{\mathrm{v}-s r c}$ in Rous sarcoma virustransformed cells. Using this recombinant plasmid, we demonstrated that c-src mRNA contains sequences which map 3' to the previously identified c-src-v-src regions of homology. In view of the small amount of c$s r c$ mRNA and protein that can be isolated from uninfected cells, this transient expression system offers a convenient source of material for further analyses of the c-src gene product.
\end{abstract}

Cellular sequences related to the Rous sarcoma virus (RSV) transforming gene have been identified in a wide variety of vertebrate species as well as in Drosophila melanogaster $(34,37)$. The products of the cellular and viral sequences are phosphoproteins of 60,000 daltons each, designated pp60 $0^{\mathrm{c}-s r c}$ and pp60 $60^{\mathrm{v}-s \mathrm{c}}$, respectively $(2,5,20,30)$. Both classes of proteins have tyrosine-specific kinase activity $(7-9,12,19,20,24,30)$. The evolutionary conservation of pp60 ${ }^{\text {c-src }}$ suggests that the protein serves an important function in normal cells. Studies of pp60 ${ }^{\mathrm{c}-s r c}$ have been hindered by the small amount of protein expressed in uninfected cells, 10 - to 100 -fold lower than that of pp60 $0^{\mathrm{v}-s \mathrm{rc}}$ in RSV-transformed cells $(5,20,30)$.

Molecular clones containing the chicken c-src locus have been isolated, and the regions of the c-src gene which contain homologies to v-src have been identified $(31,33,38-$ 40). In contrast to the v-src sequences, the c-src gene is separated by multiple introns. The RNA that is needed to code for pp60 $60^{\text {-src }}$ is ca. 1.7 kilobases $(\mathrm{kb})$; however, the csrc mRNA that has been identified by sucrose sedimentation analyses and denaturing agarose gel electrophoresis is ca. 4 to $6 \mathrm{~kb}(31,36)$. Utilizing two of the previously characterized molecular clones (40), we reconstructed 14 kilobase pairs (kbp) of cloned chicken c-src DNA in a simian virus 40 (SV40)-derived vector. When introduced into COS cells (15), the c-src-containing recombinant DNA is amplified and serves as the template for large amounts of c-src mRNA. This $4.5-\mathrm{kb}$ mRNA is translated into authentic avian pp60 ${ }^{\mathrm{c}-}$ src which has tyrosine-specific kinase activity. From Northern blot analyses, we found that c-src mRNA contains sequences which map $3^{\prime}$ to the regions of homology with $v$ src.

\section{MATERIALS AND METHODS}

Cells and DNA transfections. Primary chicken embryo fibroblasts (CEF) were prepared from 12-day-old $g s^{-}$chf $^{-}$ Marek $^{-}$embryos (Spafas Inc., Norwich, Conn.) and cul-

\footnotetext{
$\dagger$ Present address: Laboratory of Pulmonary Function and Toxicology, National Institute of Environmental Health Sciences, Research Triangle Park, NC 27709.
}

tured in Dulbecco modified medium (DME) supplemented with $10 \%$ tryptose phosphate and $5 \%$ fetal calf serum.

COS7 cells (CV-1 monkey cells transformed with an origin-defective mutant of SV40) were obtained originally from Y. Gluzman, Cold Spring Harbor Laboratory, N.Y., and cultured as previously described (15). DNA transfections were carried out as described by Mellon et al. (28). One day before transfection, COS cells were subcultured 1:4. One milliliter of plasmid DNA $(10 \mu \mathrm{g} / \mathrm{ml})$ as a calcium phosphate coprecipitate (16) was added to cells in $10-\mathrm{cm}$ dishes. After $5 \mathrm{~h}$ at $37^{\circ} \mathrm{C}$, the cells were washed with DME, and $1 \mathrm{ml}$ of $25 \%$ glycerol in DME was added for $1 \mathrm{~min}$ at room temperature. The cells were washed with medium, 10 $\mathrm{ml}$ of DME containing $10 \%$ fetal calf serum was added, and the cells were incubated at $37^{\circ} \mathrm{C}$ for 48 to $72 \mathrm{~h}$.

Molecular cloning. The recombinant phage were grown on Escherichia coli LE392, and phage DNA was purified as described previously $(26,42)$. $\lambda$ RCS 3 and $\lambda$ RCS14 DNAs were digested with HindIII, and the 12-kbp fragment from $\lambda R C S 3$ and the $4.7-\mathrm{kbp}$ fragment from $\lambda \mathrm{RCS} 14$ were isolated from an agarose gel by electroelution (27). The 12-kbp fragment from $\lambda$ RCS3 was ligated to HindIII-cut pBR322 with T4 DNA ligase and transformed into HB101. Recombinant plasmids were isolated from minilysates (18) and subjected to partial HindIII digestion. The purified 4.7-kbp $(\lambda R C S 14)$ fragment was added with T4 DNA ligase, and the mixture was transformed into HB101. Recombinants were screened by restriction endonuclease mapping, and DNA from one recombinant pCS25 with the desired orientation was prepared (4). After digestion of pCS25 with BgllII, a 14$\mathrm{kbp}$ fragment was isolated from an agarose gel by electroelution and inserted into the BamHI site of pSVOH with T4 DNA ligase. Plasmid pSVOH contains the SV40 HindIII C fragment (nucleotide 5171 to nucleotide 1042 on the SV40 map [11]) which includes the SV40 origin of replication. It does not, however, contain the pBR322 sequences inhibitory to replication in monkey cells (25). After transformation of HB101, a plasmid, pSVOHCS11, was isolated which had the desired orientation.

DNA and RNA purification. Cells were washed with phosphate-buffered saline and suspended in lysis buffer $(200 \mathrm{mM}$ Tris-hydrochloride [pH 8.5], $140 \mathrm{mM} \mathrm{NaCl}, 2 \mathrm{mM} \mathrm{MgCl}) 48$ 
to $72 \mathrm{~h}$ after transfection, and Nonidet P-40 was added to a final concentration of $0.5 \%$. After $4 \mathrm{~min}$ on ice, the nuclei were pelleted by centrifugation at $500 \times g$ for $5 \mathrm{~min}\left(4^{\circ} \mathrm{C}\right)$, and the supernatant was reserved for RNA isolation. The nuclei were lysed by addition of $1.25 \%$ sodium dodecyl sulfate (SDS), and unintegrated DNA was isolated by the method of Hirt (17). DNA was subjected to electrophoresis in $0.75 \%$ agarose gels and transferred to nitrocellulose filters (35).

Cytoplasmic supernatants were diluted with 2 volumes of TSE buffer (10 mM Tris-hydrochloride [pH 8.5], $5 \mathrm{mM}$ EDTA, 0.5\% SDS) and extracted three times with TSEsaturated phenol-chloroform-isoamyl alcohol (20:20:1 [ [vol/ vol]) and twice with chloroform-isoamyl alcohol. RNA was precipitated with ethanol and collected by centrifugation. RNA was enriched for polyadenylated $\left[\operatorname{poly}(A)^{+}\right]$sequences by oligodeoxythymidylate-cellulose chromatography (1). After fractionation by formaldehyde agarose gel electrophoresis (23), the RNA was transferred to nitrocellulose filters (41).

Hybridization. An $s r c$-specific probe was prepared from a clone containing the $3.0-\mathrm{kbp}$ EcoRI v-src fragment in pBR325 (14). This plasmid was digested with XhoI and EcoRI, and the v-src-containing fragment was purified by agarose gel electrophoresis and was recovered by electroelution (27). c-src DNA fragments used as probes in Fig. 5 were isolated as described above, and each purified fragment was labeled by nick translation to a specific activity of $1 \times 10^{8}$ to $3 \times 10^{8} \mathrm{cpm} / \mu \mathrm{g}$ and used for hybridization of filters. The specificity of each c-src probe was validated by monitoring hybridization to digested c-src DNA. Filters were prehybridized overnight at $42^{\circ} \mathrm{C}$ in a solution of $50 \%$ ( formamide, $5 \times \mathrm{SSC}(1 \times \mathrm{SSC}$ is $0.15 \mathrm{M} \mathrm{NaCl}$ plus $0.015 \mathrm{M}$ sodium citrate), $5 \times$ Denhardt solution (10), $50 \mathrm{mM} \mathrm{KP_{i }}(\mathrm{pH}$ $6.5), 0.25 \%$ SDS, and $250 \mu \mathrm{g}$ of yeast RNA per ml. Hybridizations were carried out for $48 \mathrm{~h}$ at $42^{\circ} \mathrm{C}$ in the same buffer, except that the Denhardt solution was $1 \times$. The filters were washed with two changes of $2 \times$ SSC-0.1\% SDS for $15 \mathrm{~min}$ each at room temperature and then washed with four changes of $0.1 \times \mathrm{SSC}-0.1 \% \mathrm{SDS}$ for $30 \mathrm{~min}$ each at $50^{\circ} \mathrm{C}$. The filters were exposed to Kodak XAR film or Dupont Cronex film with or without Dupont Cronex intensifying screens. csrc-specific RNA was quantitated by scanning the autoradiograph with an LKB 2202 Ultrascan laser densitometer and correcting the values for the different amounts of RNA loaded in each lane.

Immunoprecipitation and protein analysis. Labeling of cells with $\left[{ }^{35} \mathrm{~S}\right]$ methionine or $\left[{ }^{32} \mathrm{P}\right]$ phosphate was performed as described previously (2). Cells were lysed with $150 \mathrm{mM}$ $\mathrm{NaCl}-1 \%$ Triton $\mathrm{X}-100-1 \%$ sodium deoxycholate- $0.1 \%$ SDS-10 mM Tris-hydrochloride (pH 7.2)-1 mM EDTA and centrifuged at $100,000 \times g$ for $30 \mathrm{~min}$ at $4^{\circ} \mathrm{C}$. Extracts were immunoprecipitated, and the proteins were eluted and electrophoresed as described previously (21). One-dimensional peptide mapping by limited proteolysis was carried out as described by Cleveland et al. (3).

\section{RESULTS}

Construction of plasmids. Two HindIII restriction fragments were isolated from overlapping recombinant phages provided by Hidesaburo Hanafusa (40; Fig. 1). These two fragments span the c-src region of the chicken genome. A 12kbp HindIII fragment (map coordinates, -2.2 to 9.8 ) containing the entire coding region of $c-\operatorname{src}(39,40)$ was isolated from $\lambda \mathrm{RCS} 3$ and ligated into pBR322. A 4.7-kbp HindIII fragment (map coordinates, -6.9 to -2.2 ) containing a noncoding exon of c-src and 5' upstream sequences was isolated from $\lambda \mathrm{RCS} 14$ and ligated into the previous construction which had been linearized by partial HindIII digestion. Recombinants were screened by restriction endonuclease mapping. One plasmid, designated pCS25, includes both HindIII fragments in an orientation which reconstructs 16.7 kbp of chicken DNA. The intact c-src coding region and its $5^{\prime}$ and $3^{\prime}$ flanking sequences spanning $14 \mathrm{kbp}$ were removed from pCS25 by $B g$ III digestion and inserted into the $\mathrm{BamHI}$ site of pSVOH (provided by Chi-Bom Chae). This vector contains the HindIII C fragment of SV40 (11) which includes the SV40 origin of replication, two complete copies of the 72 base pair (bp) repeat required for enhancer activity (29), and the SV40 early promoter and late transcription and splice donor sites in a pBR322 derivative (25). The resulting recombinant plasmid pSVOHCS11 has the orientation shown in Fig. 1.

Replication of the vector in COS cells. To test the construction for expression of the c-src gene, pSVOHCS11 DNA was introduced into COS cells (15) by transfection using the calcium phosphate precipitate technique (16) followed by glycerol shock treatment to enhance DNA uptake (28). In all experiments COS cells that had been transfected with the vector plasmid pSVOH or COS cells that had been subjected to glycerol shock treatment alone were used as controls.

Circular DNAs containing the SV40 origin of replication that are introduced into COS cells are amplified due to the presence of the SV40 T antigen in these cells (15). Replication of pSVOHCS11 DNA in COS cells was examined at $72 \mathrm{~h}$ after transfection. The nuclei of treated cells were isolated, and unintegrated DNA was prepared by the method of Hirt (17). The extrachromosomal DNA was separated by agarose gel electrophoresis, transferred to nitrocellulose filters, and hybridized with a ${ }^{32} \mathrm{P}$-labeled probe prepared from cloned $\mathrm{v}$ src DNA (14). Lane 3 of Fig. 2A illustrates the presence of amplified pSVOHCS11 DNA in the transfected cells. No src-specific unintegrated DNA was detected in nuclei of either control COS cells (lane 2) or pSVOHCS11-transfected cells $5 \mathrm{~h}$ after the addition of DNA (data not shown).

Transcription of chicken c-src sequences in COS cells. Poly (A) ${ }^{+}$RNA was prepared from the cytoplasm of COS cells transfected with pSVOHCS11 and from the cytoplasm of CEF and was electrophoresed in adjacent lanes in a formaldehyde agarose gel (23). RNA in the gel was transferred to nitrocellulose paper and hybridized to a ${ }^{32} \mathrm{P}$-labeled $\mathrm{v}$-src probe. A predominant band was detected by hybridization of the probe to mRNA prepared from pSVOHCS11transfected COS cells (Fig. 2B, lane 3). The apparent size of this band of $\sim 4.5 \mathrm{~kb}$ is consistent with previous size estimates of c-src mRNA $(31,36)$ and corresponded to the single band hybridizing with mRNA from CEF (Fig. 2B, lane 1). However, the HindIII C fragment in the vector pSVOH contains the 5' terminal leader sequences of late mRNAs of SV40 which are ca. 200 nucleotides in length (22). The c-src mRNA produced in this system hybridized with the HindIII $\mathrm{C}$ fragment, indicating that at least some of the mRNA is initiated form the SV40 late promoter (data not shown). Longer exposure of lane 3, Fig. 2B, revealed two additional hybridizing bands of about $6 \mathrm{~kb}$ and $>10 \mathrm{~kb}$ which hybridized with the src probe and the SV40 probe. These bands probably represent minor readthrough transcripts which are initiated from the SV40 late or early promoters.

The amount of c-src mRNA produced in the pSVOHCS11transfected cells was ca. 50-fold higher than that made in CEF, as determined by a densitometer scan of the autoradiogram. Under the conditions used, no hybridization was 

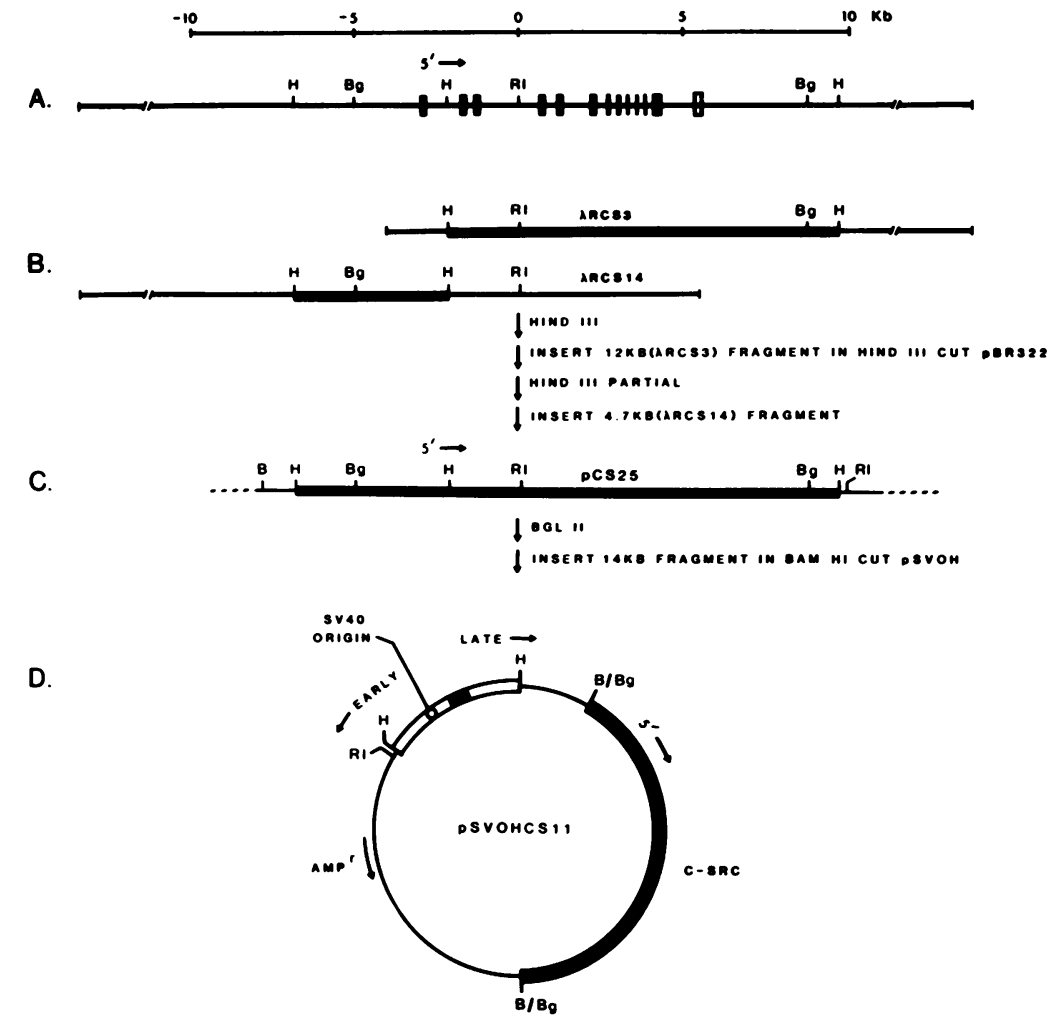

FIG. 1. Construction of a plasmid expressing pp60 ${ }^{\mathrm{c}-s r c}$. Maps A and B are from reference 40. (A) Restriction endonuclease maps of the chicken c-src locus. The 12 identified c-src exons are designated by the closed boxes as determined by electron microscopy $(33,40)$ and DNA sequencing (39). The open box indicates a portion of the carboxy-terminal region of v-src DNA which maps about 900 bp downstream from exon 12. The precise exon-intron structure of c-src is not clear in this region. The arrows designate the direction of transcription. Restriction endonucleases are abbreviated as follows: H, HindIII; Bg, BglII; RI, EcoRI; B, BamHI. (B) Overlapping c-src region inserts of $\lambda$ RCS3 and $\lambda R C S 14$ and their respective restriction maps. The c-src boundaries of the two clones are designated by thin lines. Heavy lines indicate the csrc HindIII retriction fragments isolated from each insert and used in the cloning procedures. (C) Restriction map of pCS25, a recombinant clone containing the two HindIII c-src restriction fragments inserted in the HindIII c-src site of pBR322. Thin lines denote the pBR322 sequences. (D) Restriction map of pSVOHCS11. The open box represents the SV40 HindIII C fragment. The small closed boxes in the SV40 insert indicate the 72-bp repeat sequences. The c-src BgllI fragment designated by the heavy lines was inserted in the Bam HI site of pSVOH.

detected between the v-src probe and RNA prepared from control COS cells (Fig. 2B, lane 2).

Immunoprecipitation and characterization of the c-src protein in pSVOHCS11-transfected COS cells. Cellular extracts of $\left.{ }^{35} \mathrm{~S}\right]$ methionine-labeled or $\left.{ }^{32} \mathrm{P}\right]$ phosphate-labeled pSVOHCS11-transfected COS cells were immunoprecipitated with anti-p60 serum (antiserum made against bacteriumproduced v-src [13] which is cross-reactive with avian pp60 $0^{c-s r c}$. A $60,000-M_{\mathrm{w}}$ protein was specifically immunoprecipitated with anti-p60 serum (Fig. 3A) and not with normal rabbit serum (data not shown). The protein was not immunoprecipitated from control COS cells. To confirm that the $60,000-M_{\mathrm{w}}$ protein precipitated from $\mathrm{pSVOHCS11-transfect-}$ ed COS cells was pp60 $60^{\mathrm{c}-s r c}$, the partial proteolytic cleavage map of this protein was compared with pp60 ${ }^{\text {c-src }}$ immunoprecipitated from CEF. The two cleavage maps with two concentrations of Staphylococcus aureus V8 protease are identical (Fig. 3B). This shows that the $60,000-M_{\mathrm{w}}$ protein is $\mathrm{pp} 60^{\mathrm{c}-s r}$ and not $\mathrm{pp} 60^{\mathrm{v}-s r c}$ since the carboxy-terminal peptides of the two proteins can be distinguished by V8 mapping ( 5 ,

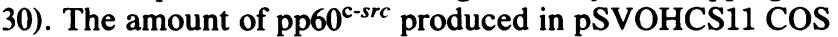
cells 48 to $60 \mathrm{~h}$ after transfection is ca. $0.025 \%$ of the total labeled soluble protein from these cells and is consistent with the amount of $\mathrm{pp} 60^{\mathrm{v}-s \mathrm{rc}}$ produced in RSV-transformed cells $(5,20$; unpublished data).
As shown previously $(7,30)$, when extracts of CEF are immunoprecipitated with tumor-bearing rabbit serum crossreactive with pp60-src and incubated with $\left[\gamma_{-}{ }^{32} \mathrm{P}\right] \mathrm{ATP}$, the $s r c$ protein catalyzes the transfer of phosphate to a tyrosine residue in the heavy chain of the tumor-bearing rabbit immunoglobulin. In addition, when partially purified pp $60^{c-s r c}$ is incubated with $\left[\gamma^{32} \mathrm{P}\right] \mathrm{ATP}$, the protein undergoes autophosphorylation (32). We therefore examined the pp $60^{c-s r c}$ precipitated from pSVOHCS11-transfected COS cells for protein kinase activity. Cellular lysates from control COS cells or pSVOHCS11-transfected COS cells were immunoprecipitated with tumor-bearing rabbit serum crossreactive with avian or mammalian pp60 $0^{\text {c-src }}$ (a gift of J. S. Brugge), and the complex was incubated with $\left[\gamma^{-}{ }^{32} \mathrm{P}\right] \mathrm{ATP}$ in a phosphotransferase assay as described previously (8). Lysates from pSVOHCS11-transfected cells exhibited greater levels of pp60 ${ }^{\text {c-src }}$ kinase activity than lysates from control COS cells (Fig. 4, lanes 1 and 2). No phosphorylation of immunoglobulin $\mathbf{G}$ occurred when normal rabbit serum was used to immunoprecipitate extracts of pSVOHCS11-transfected COS cells (lane 3). Some preparations of anti-p60 sera made against bacterium-produced $v-s r c$ recognize primarily pp60 ${ }^{\text {c-src }}$ from avian cells and allow autophosphorylation of the $s r c$ protein in protein kinase assays, but the immunoglobulin $G$ does not become phosphorylated (13). One such 


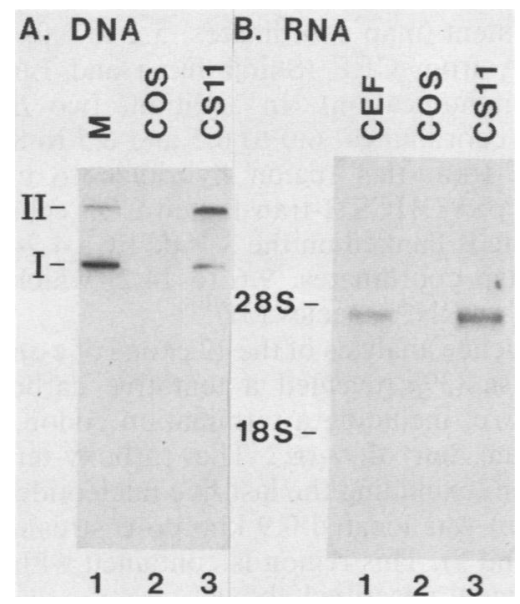

FIG. 2. (A) Replication of pSVOHCS11 DNA in COS cells. COS cells were transfected with pSVOHCS11 DNA as described in the text. Seventy-two hours later, nuclei were isolated and low-molecular-weight DNA was prepared as described by Hirt (17). One-fourth of the DNA sample was fractionated by electrophoresis on a $0.75 \%$ agarose gel, transferred to nitrocellulose filters. hybridized with a ${ }^{32} \mathrm{P}$-labeled $s r c$-specific probe, and autoradiographed. Lane 1, $10 \mathrm{ng}$ of pSVOHCS11 DNA; lane 2, DNA from nuclear lysates of control COS cells; lane 3. DNA from nuclear lysates of COS cells transfected with pSVOHCS11 DNA. The positions of form I and form II DNA are indicated. (B) Transcription of pSVOHCS11 DNA in COS cells. Poly $(\mathrm{A})^{+}$RNA was extracted from the cytoplasm of cells and electrophoresed in adjacent lanes through a $1.2 \%$ formaldehyde agarose gel. The RNA was transferred to nitrocellulose. hybridized with a ${ }^{32} \mathrm{P}$-labeled $s r c$-specific probe, and autoradiographed. Lane 1. $20 \mu \mathrm{g}$ of $\operatorname{poly}(\mathrm{A})^{+}$RNA from uninfected CEF cells; lanes 2 and 3, 1 $\mu \mathrm{g}$ of poly $(\mathrm{A})^{+}$RNA from control COS cells (lane 2) or pSVOHCS11-transfected COS cells (lane 3 ). The positions of rRNA size markers are indicated.

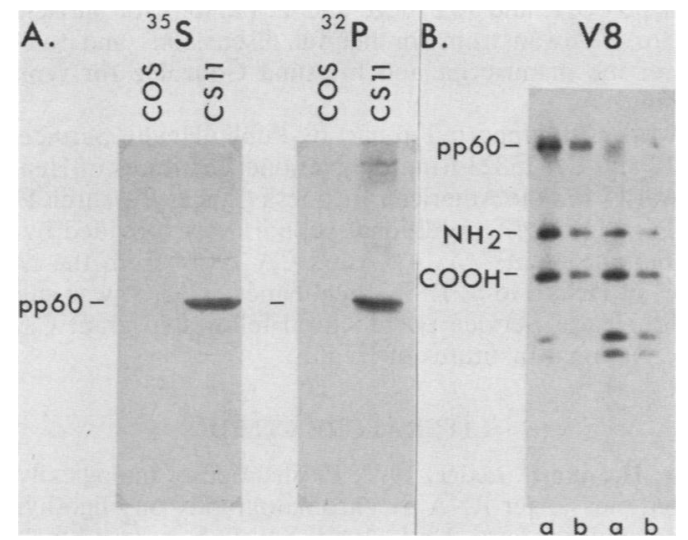

FIG. 3. (A) Immunoprecipitation of $p p 60^{\mathrm{c}-s \mathrm{rc}}$ from COS cells transfected with pSVOHCS11 DNA. Control COS cells or COS cells that had been transfected with pSVOHCS11 DNA were labeled with $\left[{ }^{35} \mathrm{~S}\right]$ methionine or $\left[{ }^{32} \mathrm{P}\right]$ phosphate. After immunoprecipitation of extracts with anti-p60 serum, the samples were electrophoresed in SDS-polyacrylamide gels and autoradiographed. (B) Partial proteolytic cleavage of pp60 $0^{\mathrm{c}-s r c}$. The [32 P]phosphate-labeled c-src protein was immunoprecipitated from pSVOHCS11-transfected COS cells (lane a) and from uninfected CEF (lane b) and was excised from preparative SDS-polyacrylamide gels. The protein was subjected to limited proteolysis during reelectrophoresis as previously described (3). Digestion was with 5 and $50 \mathrm{ng}$ of $S$. aureus V8 protease. The two large fragments of pp60 $0^{\mathrm{c}-s / \mathrm{c}}$ which are the amino and carboxy termini, are designated $\mathrm{NH}_{2}$ and $\mathrm{COOH}$, respectively (6). The $\left[{ }^{35} \mathrm{~S}\right] \mathrm{methionine}$ protein was not subjected to partial proteolytic cleavage analysis.

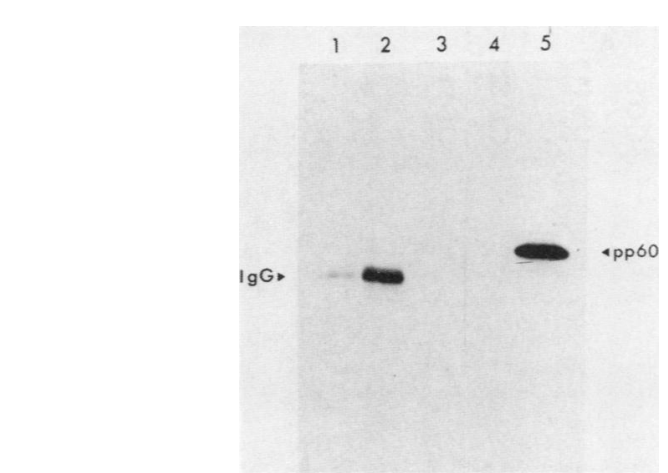

FIG. 4. Analysis of pp60-src-specific kinase activities in lysates from pSVOHCS11-transfected COS cells. After immunoprecipitation of equal amounts of protein from control COS cells (lanes 1 and 4) or pSVOHCS11-transfected COS cells (lanes 2, 3, and 5), the immune complexes were incubated at room temperature for $10 \mathrm{~min}$ with $10 \mathrm{mM}$ Tris-hydrochloride ( $\mathrm{pH} 7.5$ ) $5 \mathrm{mM} \mathrm{MgCl},-1 \mu \mathrm{M}[\gamma$ ${ }^{32}$ P]ATP $(2900 \mathrm{Ci} / \mathrm{mmol}$; New England Nuclear Corp. Boston. Mass.). Extracts were immunoprecipitated with tumor-bearing rabbit serum (lanes 1 and 2) normal rabbit serum (lane 3), or anti-p60 serum (lanes 4 and 5). Proteins were then analyzed by polyacrylamide gel electrophoresis and autoradiography. IgG, Immunoglobulin G.

preparation of rabbit anti-p60 serum (a gift of J. T. Parsons) was used to demonstrate autophosphorylation of pp60 6 -src precipitated from pSVOHCS11-transfected COS cells (Fig. 4, lane 5). Phosphoamino acid analysis of these reactions revealed that the major amino acid phosphorylated was tyrosine (data not shown).

Mapping of the 3' end of the c-src mRNA. Since the amount of c-src mRNA produced in pSVOHCS11-transfected COS cells was at least 50 -fold greater than that made in CEF, csrc DNA regions that were transcribed into mRNA were examined. Three adjacent restriction fragments (Fig. 5) spanning the $3^{\prime}$ flanking region of the c-src gene were isolated, and probes were prepared and hybridized to poly(A) ${ }^{+}$RNA from pSVOHCS11-transfected COS cells (Fig. 5). Probe A contains sequences from a 1.1-kbp SacIBamHI fragment (map coordinates, 4.9 to 6.0). The SacI site is located $10 \mathrm{bp}$ downstream from the c-src termination codon described by Takeya and Hanafusa (39). Probe B is the adjacent 500-bp BamHI fragment to the right (map coordinates, 6.0 to 6.5 ), whereas probe $C$ is the $2.3-\mathrm{kbp}$ $B a m H I$ fragment to the right of and adjacent to the fragment used as probe B (map coordinates, 6.5 to 8.8). All three probes hybridized with the $4.5-\mathrm{kb} \mathrm{c}-\mathrm{src}$ mRNA produced in pSVOHCS11-transfected COS cells (Fig. 5A, B, and C). There was no detectable hybridization, under the conditions used, with RNA prepared from control COS cells. In addition, a 3.4-kbp SacI-SacI fragment (map coordinates, 1.5 to 4.9) which contains most of the c-src coding region also hydridized to the $4.5-\mathrm{kb}$ mRNA (data not shown). Thus, csrc mRNA is transcribed from regions as far as $500 \mathrm{bp}$ downstream from the rightward-most region of the c-src locus having homology with v-src. However, the precise exon-intron structure of the $3^{\prime}$ flanking sequences cannot be determined from this analysis.

\section{DISCUSSION}

We have demonstrated that a plasmid carrying the SV40 origin of DNA replication, the 72-bp repeat sequences, the SV40 early and late promoters, and the 14-kbp region of the 


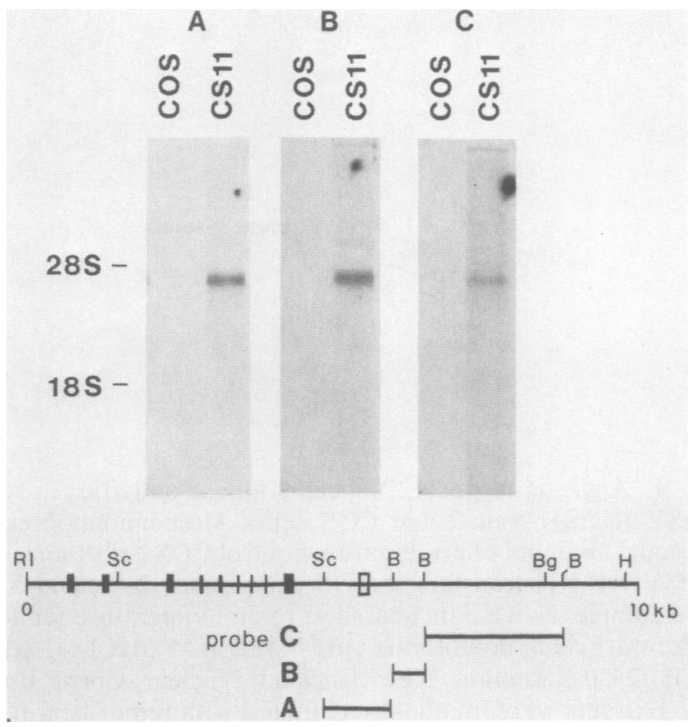

FIG. 5. Northern blot analysis of RNA from pSVOHCS11-transfected COS cells. Poly(A) ${ }^{+}$RNA ( $1 \mu \mathrm{g}$ per lane) from cytoplasmic extracts of control COS cells or pSVOHCS11-transfected COS cells was electrophoresed in adjacent lanes through a $1.2 \%$ formaldehyde agarose gel. The RNA was transferred to a nitrocellulose filter, and the filter was cut into strips and hybridized with probes A, B, and C as indicated above the lanes. The positions of rRNA size markers are indicated. The c-src restriction map is the 10-kbp EcoRI-HindIII fragment (map coordinates, 0 to 10) as shown in Fig. 1A. Exons 4 to 12 are designated by the closed boxes. The open box designates the $v$-src carboxy-terminal region. Restriction endonucleases are abbreviated as follows: H, HindIII; Bg, BglII; RI, EcoRI; B, BamHI; Sc, SacI.

chicken genome encoding the c-src gene with its $5^{\prime}$ and $3^{\prime}$ flanking regions is capable of expressing high levels of c-src mRNA and pp60 $60^{\text {-src }}$.

The c-src mRNA transcript encoded by this plasmid migrates to the same position in denaturing formaldehyde agarose gels as does c-src mRNA prepared from CEF and is present in 50-fold-greater amounts. Hybridization experiments indicate that at least some of the c-src mRNA is initiated from the SV40 late promoter.

The large amount of $\mathrm{pp} 60^{\mathrm{c}-s r c}$ produced in this system is equal to the amount of $\mathrm{pp} 60^{\mathrm{v}-\mathrm{src}}$ produced in RSV-transformed cells. In addition, the $\mathrm{pp}^{\mathrm{c}} \mathrm{c}^{\mathrm{c} s \mathrm{rc}}$ synthesized in pSVOHCS11-transfected COS cells has the same protease cleavage map as pp60-src isolated from CEF and possesses an intrinsic protein kinase activity. This system has been useful in identifying monoclonal antibodies prepared against p60 ${ }^{\mathrm{v}-s r c}$ that are cross-reactive with pp60 $0^{\mathrm{c}-s r c}$ (S. A. Parsons, J. T. Parsons, and T. M. Gilmer, unpublished data).

The mRNA for c-src is known to be ca. 4 to $4.5 \mathrm{~kb}$ by denaturing agarose gel electrophoresis (31; Fig. 2B). This amount of information is considerably greater than the 1.7 $\mathrm{kbp}$ of $\mathrm{c}-\mathrm{src}$ information that was transduced to make the RSV genome $(38,39)$. Hybridization analysis of Northern blots with DNA restriction fragments from the c-src locus indicates that at least some of the additional information is derived from sequences mapping $3^{\prime}$ to the $\mathrm{v}$-src/c-src regions of homology. One of the fragments which hybridizes with c$s r c$ mRNA produced in pSVOHCS11-transfected COS cells is a $1.1-\mathrm{kbp}$ SacI-Bam HI fragment (map coordinates, 4.9 to $6.0)$ that contains homology with the $3^{\prime}$ terminal region of $v$ src. Furthermore, the SacI-BamHI fragment and a NcoI-
BamHI fragment (map coordinates, 5.2 to 6.0) hybridize to c-src mRNA from CEF (Shinji Iijma and Lu-Hai Wang, personal communication). In addition, two BamHI fragments (map coordinates, 6.0 to 6.5 and 6.5 to 8.8 ) mapping downstream from this region hybridize to c-src mRNA produced in pSVOHCS11-transfected COS cells. However, the c-src gene is flanked on the 3' side by a 4.7-kbp HindIII fragment (map coordinates, 9.6 to 14.2 ) which hybridized with a $2.0-\mathrm{kb}$ mRNA species (31).

DNA sequence analysis of the 12 exons of c-src by Takeya and Hanafusa (39) revealed a tentative carboxy-terminal region of $\mathrm{c}-\mathrm{src}$, including a termination codon, which was different than that of v-src. The carboxy-terminal v-src coding region (excluding the last five nucleotides and termination codon) was located $0.9 \mathrm{kbp}$ downstream of exon 12 (39, Fig. 1 and 5). This region is contained within the SacIBamHI fragment described above.

An alternative possibility is that this $3^{\prime}$-most region of homology between $v$-src and c-src represents a 13th exon which contains the coding region for the carboxy terminus of c-src (38). A polyadenylation site for RNA has not been identified in either c-src region by DNA sequence analysis.

The data presented in this paper suggest that c-src DNA sequences containing homologies to the v-src carboxy terminus (exon 13) may be transcribed into c-src mRNA. Additional sequences within $3^{\prime}$ of this region are also transcribed. The precise structure of the c-src mRNA in this $3^{\prime}$ terminal region and the determination of the c-src $3^{\prime}$ carboxy-terminal coding region can be determined most directly by analysis of cDNA clones of c-src mRNA. COS cells transiently expressing high levels of c-src mRNA should provide a convenient source of RNA for this purpose.

\section{ACKNOWLEDGMENTS}

I thank $\mathrm{H}$. Hanafusa for providing $\lambda \mathrm{RCS} 3$ and $\lambda \mathrm{RCS} 14, \mathrm{C} . \mathrm{-B}$. Chae for pSVOH, and J. Brugge and T. Parsons for antisera. I am grateful to R. Swanstrom for helpful discussions and for critical reading of the manuscript and to Alma Gonzalez for typing this manuscript.

This work was supported in part by Public Health Service grants CA 21117 and CA 15823 from the National Institutes of Health and by an award from the American Business Cancer Research Foundation to R. L. Erikson. Additional support was provided by Public Health Service grants AI 14377 and CA 19014 from the National Institutes of Health to S. L. Bachenheimer. T.M.G. was supported by Public Health Service postdoctoral fellowship grant CA 06839 from the National Institutes of Health.

\section{LITERATURE CITED}

1. Aviv, H., and P. Leder. 1972. Purification of biologically active globin messenger RNA by chromatography on oligothymidylic acid-cellulose. Proc. Natl. Acad. Sci. U.S.A. 69:1408-1412.

2. Brugge, J. S., and R. L. Erikson. 1977. Identification of a transformation specific antigen induced by an avian sarcoma virus. Nature (London) 269:346-348.

3. Cleveland, D. W., S. G. Fischer, M. W. Kirschner, and U. K. Laemmli. 1977. Peptide mapping by limited proteolysis in sodium dodecylsulfate and analysis by gel electrophoresis. J. Biol. Chem. 252:1102-1106.

4. Clewell, D. B., and D. R. Helinski. 1972. Effect of growth conditions on the formation of the relaxation complex of supercoiled ColE1 deoxribonucleic acid and protein in Escherichia coli. J. Bacteriol. 110:1135-1146.

5. Collett, M. S., J. S. Brugge, and R. L. Erikson. 1978. Characterization of a normal avian cell protein related to the avian sarcoma virus transforming gene product. Cell 15:1363-1369.

6. Collett, M. S., E. Erikson, and R. L. Erikson. 1979. Structural analysis of the avian sarcoma virus transforming protein: sites 
of phosphorylation. J. Virol. 29:770-781.

7. Collett, M. S., E. Erikson, A. F. Purchio, J. S. Brugge, and R. L. Erikson. 1979. A normal cell protein similar in structure and function to the avian sarcoma virus transforming gene product. Proc. Natl. Acad. Sci. U.S.A. 76:3159-3163.

8. Collett, M. S., and R. L. Erikson. 1978. Protein kinase activity associated with the avian sarcoma virus src gene product. Proc. Natl. Acad. Sci. U.S.A. 75:2021-2024.

9. Collett, M. S., A. F. Purchio, and R. L. Erikson. 1980. Avian sarcoma virus-transforming protein, $\mathrm{pp} 60^{\mathrm{sic}}$, shows protein $\mathrm{ki}$ nase activity for tyrosine. Nature (London) 285:167-169.

10. Denhardt, D. T. 1966. A membrane-filter technique for the detection of complementary DNA. Biochem. Biophys. Res. Commun. 23:641-646.

11. Fiers, W., R. Contreras, G. Haegeman, R. Rogiers, A. Van de Voorde, H. Van Heuverswyn, J. Van Herreweghe, G. Volckaert, and M. Ysebaert. 1978. Complete nucleotide sequence of SV40 DNA. Nature (London) 273:113-120.

12. Gilmer, T. M., and R. L. Erikson. 1981. Rous sarcoma virus transforming protein, $60^{\text {src }}$. expressed in $E$. coli, functions as a protein kinase. Nature (London) 294:771-773.

13. Gilmer, T. M., and R. L. Erikson. 1983. Development of antipp60 src serum with antigen produced in Escherichia coli. J. Virol. 45:462-465.

14. Gilmer, T. M., J. T. Parsons, and R. L. Erikson. 1982. Construction of plasmids for expression of Rous sarcoma virus transforming protein, p60 sre, in Escherichia coli. Proc. Natl. Acad. Sci. U.S.A. 79:2152-2156.

15. Gluzman, Y. 1981. SV40-transformed simian cells support the replication of early SV40 mutants. Cell 23:175-182.

16. Graham, F. L., and A. J. Van der Eb. 1973. A new technique for the assay of infectivity of human adenovirus 5 DNA. Virology 52:456-457.

17. Hirt, B. 1967. Selective extraction of polyoma DNA from infected mouse cell cultures. J. Mol. Biol. 26:365-369.

18. Holmes, D. S., and M. Quigley. 1981. A rapid method for the preparation of bacterial plasmids. Anal. Biochem. 114:193-197.

19. Hunter, T., and B. Sefton. 1980. Transforming gene product of Rous sarcoma virus phosphorylates tyrosine. Proc. Natl. Acad. Sci. U.S.A. 77:1311-1315.

20. Karess, R. E., W. S. Hayward, and H. Hanafusa. 1979. Cellular information in the genome of recovered avian sarcoma virus directs the synthesis of transforming protein. Proc. Natl. Acad. Sci. U.S.A. 76:3154-3158.

21. Laemmli, U. K. 1970. Cleavage of structural proteins during the assembly of the head of bacteriophage T4. Nature (London) 227:680-685.

22. Lai, C.-J., R. Dhar, and G. Khoury. 1978. Mapping the spliced and unspliced late lytic SV40 RNAs. Cell 14:971-982.

23. Lehrach, H., D. Diamond, J. M. Wozney, and H. Boedtker. 1977. RNA molecular weight determinations of gel electrophoresis under denaturing conditions, a critical reexamination. Biochemistry 16:4743-4751.

24. Levinson, A. D., H. Oppermann, L. Levintow, H. E. Varmus, and J. M. Bishop. 1978. Evidence that the transforming gene of avian sarcoma virus encodes a protein kinase associated with a phosphoprotein. Cell 15:561-572.

25. Lusky, M., and M. Botchan. 1981. Inhibition of SV40 replication in simian cells by specific pBR322 DNA sequences. Nature (London) 293:79-81.

26. Maniatis, T., R. C. Hardison, E. Lacy, J. Lauer, C. O'Connell, D. Quon, D. K. Sim, and A. Efstratiadis. 1978. The isolation of structural genes from libraries of eucaryotic DNA. Cell 15:687701.
27. McDonell, M. W., M. N. Simon, and F. W. Studier. 1977. Analysis of restriction fragments of T7 DNA and determination of molecular weights by electrophoresis in neutral and alkaline gels. J. Mol. Biol. 110:119-146.

28. Mellon, P., V. Parker, Y. Gluzman, and T. Maniatis. 1981. Identification of DNA sequences required for transcription of the human $\alpha \mathrm{l}$-globin gene in a new SV40 host-vector system. Cell 27:279-288.

29. Moreau, P., R. Hen, B. Wasylyk, R. Everett, M. P. Gaub, and P. Chambon. 1981. The SV40 72 base-pair repeat has a striking effect on gene expression both in SV40 and other chimeric plasmids. Nucleic Acids Res. 9:6047-6068.

30. Oppermann, H., A. D. Levinson, H. E. Varmus, L. Levintow, and J. M. Bishop. 1979. Uninfected vertebrate cells contain a protein that is closely related to the product of the avian sarcoma virus transforming gene (src). Proc. Natl. Acad. Sci. U.S.A. 76:1804-1808.

31. Parker, R. C., H. E. Varmus, and J. M. Bishop. 1981. Cellular homologue (c-src) of the transforming gene of Rous sarcoma virus: isolation, mapping, and transcriptional analysis of c-src and flanking regions. Proc. Natl. Acad. Sci. U.S.A. 78:58425846.

32. Purchio, A. F., E. Erikson, M. S. Collett, and R. L. Erikson. 1980. Partial purification and characterization of $\mathrm{pp} 60^{\text {surc }}$. a normal cellular protein structurally and functionally related to the avian sarcoma virus src gene product. p. 1203-1215. In O. M. Rosen and E. G. Krebs (ed.), Protein phosphorylation. Cold Spring Harbor conferences on cell proliferation, vol. 8. Cold Spring Harbor Laboratory, Cold Spring Harbor, N.Y.

33. Shalloway, D., A. D. Zelenetz, and G. M. Cooper. 1981. Molecular cloning and characterization of the chicken gene homologous to the transforming gene of Rous sarcoma virus. Cell 24:531541.

34. Shilo, B. Z., and R. A. Weinberg. 1981. DNA sequences homologous to vertebrate oncogenes are conserved in Drosophila melanogaster. Proc. Natl. Acad. Sci. U.S.A. 78:6789-6792.

35. Southern, E. M. 1975 . Detection of specific sequences among DNA fragments separated by gel electrophoresis. J. Mol. Biol. 98:503-517.

36. Spector, D. H., B. Baker, H. E. Varmus, and J. M. Bishop. 1978. Characterization of cellular RNA related to the transforming gene of avian sarcoma viruses. Cell. 13:381-386.

37. Spector, D. H., H. E. Varmus, and J. M. Bishop. 1978. Nucleotide sequences related to the transforming gene of avian sarcoma virus are present in the DNA of uninfected vertebrates. Proc. Natl. Acad. Sci. U.S.A. 75:4102-4106.

38. Swanstrom, R., R. C. Parker, H. E. Varmus, and J. M. Bishop. 1983. Transduction of a cellular oncogene: the genesis of Rous sarcoma virus. Proc. Natl. Acad. Sci. U.S.A. 80:2519-2523.

39. Takeya, T., and H. Hanafusa. 1983. Structure and sequence of the cellular gene homologous to the RSV src gene and the mechanism for generating the transforming virus. Cell 32:881890.

40. Takeya, T., H. Hanafusa, R. P. Junghans, G. Ju, and A. M. Skalka. 1981. Comparison between the viral transforming gene $(s r c)$ of recovered avian sarcoma virus and its cellular homolog. Mol. Cell. Biol. 1:1024-1037.

41. Thomas, P. 1980 . Hybridization of denatured RNA and small DNA fragments transferred to nitrocellulose. Proc. Natl. Acad. Sci. U.S.A. 77:5201-5205.

42. Yamamoto, K. R., B. M. Alberts, R. Benzinger, L. Lawhorne, and G. Treiber. 1970. Rapid bacteriophage sedimentation in the presence of polyethylene glycol and its application to large-scale virus purification. Virology. 40:734-744. 